\title{
ANALISIS PEMBELIAN IKAN SEGAR DAN IKAN OLAHAN PADA IBU BEKERJA DAN IBU TIDAK BEKERJA
}

\author{
Tevi Karuniawati ${ }^{\left.{ }^{*}\right)}$, Arif Satria ${ }^{2}$ dan Lilik Noor Yuliati ${ }^{3}$ \\ ${ }^{1}$ Kementerian Kelautan dan Perikanan, Gd Mina Bahari III Lt. 4 Jl. Medan Merdeka Timur No. 16 Jakarta Pusat \\ 10110, Indonesia \\ ${ }^{2}$ Departemen Sains Komunikasi dan Pengembangan Masyarakat, Fakultas Ekologi Manusia, Institut Pertanian \\ Bogor, Bogor 16680, Indonesia \\ ${ }^{3}$ Departemen Ilmu Keluarga dan Konsumen, Fakultas Ekologi Manusia, Institut Pertanian Bogor, Bogor 16680, \\ Indonesia \\ *) Email: tevikaruniawati@gmail.com
}

\begin{abstract}
Abstrak
Penelitian ini bertujuan untuk menganalisis faktor yang memengaruhi pembelian ikan pada ibu bekerja dan tidak bekerja di Kota Bogor, Provinsi Jawa Barat. Responden berjumlah 200 orang yang dipilih secara purposive. Data penelitian dikumpulkan dengan wawancara dan dianalisis dengan menggunakan analisis konjoin, Fishbein, dan Logit. Hasil penelitian menunjukkan bahwa ibu bekerja maupun ibu tidak bekerja lebih mementingkan kondisi ikan dibandingkan dengan jenis ikan. Pengetahuan ibu bekerja dan tidak bekerja relatif sama mengenai kandungan, jenis, dan cara pengolahan ikan. Sikap ibu bekerja dan tidak bekerja juga sama, yaitu lebih memilih ikan segar dibandingkan dengan ikan olahan. Pembelian ikan segar dan ikan olahan dilihat dari frekuensi dan kuantitas pembelian. Faktor yang memengaruhi frekuensi pembelian ikan segar adalah pengeluaran keluarga, preferensi, dan pengetahuan. Sementara itu, frekuensi pembelian ikan olahan dipengaruhi oleh pendidikan, besar keluarga, dan sikap. Selanjutnya, faktor yang memengaruhi kuantitas pembelian ikan segar adalah pengeluaran keluarga, sedangkan kuantitas pembelian ikan olahan dipengaruhi oleh besar keluarga.
\end{abstract}

Kata kunci: konsumsi ikan, pembelian ikan, pengetahuan, preferensi, sikap

\section{Analysis of Fresh and Processed Fish Purchasing of Working Mothers and Housewifes}

\begin{abstract}
This research aimed to analyze the factors that influence fresh and processed fish purchasing of working mothers and housewives in Bogor City, West Java. This research involved 200 peoples that were selected purposively. Data were collected by interview and were analyzed by conjoint, Fishbein, and Logit analysis. The result showed that both working mothers and housewives more concerned about fish condition rather than fish types. The knowledge about content, type, and processing of fish of both working mothers and housewives were relatively similar. The attitude of both working mothers and housewives was same. Both of them prefer fresh fish rather than processed fish. Purchasing of fresh and processed fish was measured by the frequency and quantity of purchasing. The factors that affect the frequency of fresh fish purchasing were family expenditure, preference, and knowledge, while the frequency of processed fish purchasing was influenced by education, family size, and attitude. Furthermore, the factors that affect the quantity of fresh fish purchasing were family expenditure, while the quantity of processed fish purchasing was influenced by family size.
\end{abstract}

Keywords: attitude, fish consumption, fish purchase, knowledge, preference

\section{PENDAHULUAN}

Ikan merupakan bahan pangan yang memiliki keunggulan dibandingkan dengan bahan pangan lainnya (Ditjen PDSPKP, 2015). Penelitian yang telah dilakukan, baik di Indonesia maupun luar negeri membuktikan bahwa ikan memiliki kandungan gizi esensial yang sangat bermanfaat bagi kesehatan dan kecerdasan, yaitu protein, karbohidrat, vitamin, mineral, serta asam lemak omega 3, 6 dan 9. Penelitian Soccol dan Oetterer (2003) dan Susanto dan Fahmi (2012) menyebutkan bahwa ikan kaya akan gizi yaitu protein, mineral dan lemak, serta penghasil terbesar asam lemak omega 3 (PUFA), khususnya eicosapentaenoic (EPA) dan docosahexaenoic (DHA) yang bermanfaat bagi kesehatan. Berdasarkan kandungan gizi dan manfaat dari ikan, upaya peningkatan konsumsi ikan menjadi hal penting untuk terus dilakukan secara 
berkesinambungan. Upaya peningkatan konsumsi ikan tidak saja menjadi perhatian Bangsa Indonesia. Negara-negara belahan dunia lain juga melaksanakan berbagai upaya untuk meningkatkan konsumsi ikan per kapita penduduknya. Jepang dan Amerika adalah contoh negara yang meningkatkan konsumsi ikan penduduknya (Ditjen PDSPKP, 2015).

Sokib, Palupi, dan Suharjo (2012) menyatakan bahwa Indonesia sangat berpeluang untuk menjadikan ikan sebagai sumber protein utama sebagai upaya untuk meningkatkan gizi masyarakat. Hal ini dikarenakan Indonesia memiliki potensi ikan yang melimpah, baik dari hasil tangkapan maupun dari hasil budidaya. Realisasi produksi perikanan tangkap pada tahun 2014 adalah sebanyak 6.200.180 ton. Capaian tersebut terdiri atas produksi perikanan laut sebanyak 5.779 .990 ton dan perikanan umum darat (PUD) sebanyak 420.190 ton. Pencapaian produksi perikanan budidaya di Indonesia pada tahun 2014 sebesar 14,52 juta ton. Sementara itu, jumlah produk olahan hasil perikanan tahun 2014 sebesar 5,37 juta ton yang terdiri dari jumlah produk olahan Unit Pengolah Ikan (UPI) skala UMKM sebesar 3,61 juta ton dan jumlah produk olahan UPI skala besar sebesar 1,76 juta ton (KKP, 2014).

Potensi produksi perikanan tersebut seharusnya mampu meningkatkan konsumsi ikan di Indonesia. Namun, besarnya potensi perikanan Indonesia tidak diikuti dengan tingkat konsumsi ikan dalam negeri yang tinggi pula. Pada tahun 2014, tingkat konsumsi ikan di Indonesia sebesar 37,89 kg/kapita (KKP, 2014). Tingkat konsumsi ikan di Indonesia masih berada di bawah tingkat konsumsi ikan di beberapa negara (Sokib, Palupi, \& Suharjo, 2012). Tingkat konsumsi ikan pada tahun 2009 di Jepang adalah $110 \mathrm{~kg} / \mathrm{kap}$, Korea Selatan sebesar $85 \mathrm{~kg} / \mathrm{kapita}$, Amerika Serikat sebesar $80 \mathrm{~kg} / \mathrm{kapita}$, Singapura sebesar $80 \mathrm{~kg} / \mathrm{kapita}$, Hongkong sebesar 85 kg/kapita, dan Malaysia sebesar 45 kg/kapita.

Berdasarkan kajian Ditjen PDSPKP (2015), penyebab dari rendahnya konsumsi ikan adalah kurangnya pasokan ikan yang kontinyu dan bermutu; kurangnya sarana penjualan ikan yang representatif, bersih, dan sesuai dengan keinginan konsumen; belum berkembangnya sistem logistik dan distribusi ikan yang mampu mengirimkan ikan dari daerah produsen sampai ke konsumen di daerah pelosok maupun pegunungan; dan juga kurangnya ketersediaan variasi menu maupun olahan ikan di pasar. Selain itu, konsumsi ikan antarwilayah di
Indonesia belum merata. Wilayah Indonesia Bagian Timur yang antara lain terdiri atas daerah di Pulau Sulawesi, Maluku, dan Papua diketahui memiliki tingkat konsumsi ikan lebih tinggi dibandingkan dengan daerah di Indonesia Bagian Barat, khususnya Pulau Jawa.

Rendahnya konsumsi ikan masyarakat Indonesia juga ditunjukkan oleh rendahnya permintaan produk perikanan. Beberapa penyebabnya adalah kurangnya pengetahuan masyarakat tentang informasi kandungan gizi dan manfaat makan ikan dan masih terdapat persepsi yang salah tentang ikan di masyarakat. Persepsi tersebut antara lain makan ikan menyebabkan anak cacingan, air susu ibu menjadi amis, dapat menimbulkan alergi, dan gatal-gatal. Selain itu, preferensi masyarakat terhadap ikan masih belum banyak dikaji, sehingga belum diketahui jenis dan bentuk ikan yang disukai oleh masyarakat. Menurut Harlin (2008), pengukuran terhadap preferensi konsumen sangat penting dilakukan karena sebagai dasar untuk menarik minat konsumen terhadap suatu produk tertentu dan sebagai acuan dalam mengembangkan program yang dapat meningkatkan loyalitas konsumen. Berdasarkan hal tersebut dapat dikatakan bahwa pengukuran tingkat preferensi konsumen berkaitan dengan pengukuran faktor-faktor yang membentuk sebuah preferensi konsumen.

Sikap masyarakat terhadap ikan juga menjadi hal yang perlu dikaji. Sikap menjadi salah satu faktor yang berpengaruh terhadap perilaku ibu dalam menyediakan ikan sebagai menu keluarga (Waysima et al., 2011a). Hasil penelitian Waysima et al. (2011b) juga menyebutkan bahwa sikap afektif ibu terhadap ikan laut berpengaruh nyata dalam meningkatkan apresiasi anak untuk mengonsumsi ikan laut. Konsumsi ikan sangat bermanfaat dan sangat baik bagi kesehatan. Hal ini merupakan pertimbangan utama bagi ibu dalam pemenuhan gizi keluarga.

Kegiatan memasak makanan berbahan ikan membutuhkan waktu yang lebih lama untuk penyajiannya sehingga kurang diminati oleh ibu bekerja yang mempunyai waktu terbatas dalam menyiapkan menu bagi keluarga. Meskipun demikian, kandungan gizi ikan yang sangat baik bagi kesehatan membuat ibu bekerja memilih alternatif ikan olahan sebagai pengganti ikan segar. Produksi ikan olahan yang biasa ditemukan meliputi ikan asin kering/tawar, ikan pindang, ikan peda, ikan presto, ikan kaleng, ikan beku, ikan asap, dan fish jelly. Menurut 
Salaa (2015), peran ibu rumah tangga yang bekerja di luar sebagai pencari nafkah ternyata tidak meninggalkan tugas dan tanggung jawabnya sebagai seorang istri dan seorang ibu dalam keluarganya sehingga perilaku ibu menyediakan ikan dalam menu keluarga didasarkan bahwa ibu sebagai penentu menu keluarga (Sumarwan, 2014). Berdasarkan pertimbangan tersebut, maka tujuan dari penelitian ini adalah untuk menganalisis faktor yang memengaruhi pembelian ikan segar dan ikan olahan pada ibu bekerja dan ibu tidak bekerja.

\section{METODE}

Penelitian ini menggunakan desain cross sectional dengan metode survei. Penelitian dilakukan di Kota Bogor, Provinsi Jawa Barat. Pengambilan data dilakukan pada bulan Mei sampai dengan bulan Juni tahun 2016. Responden pada penelitian ini adalah ibu bekerja dan ibu tidak bekerja di Kota Bogor dengan jumlah responden masing-masing 100 orang. Responden dipilih secara purposive dengan kriteria sudah menikah, merupakan penentu menu dalam keluarga, dan melakukan pembelian ikan dalam sebulan terakhir.

Data primer dalam penelitian ini meliputi karakteristik demografi, preferensi, persepsi, pengetahuan, sikap, dan perilaku pembelian ikan segar dan ikan olahan. Data ini dikumpulkan melalui wawancara dengan bantuan kuesioner.

Karakteristik ekonomi sosial demografi resonden meliputi usia, pendidikan terakhir, pekerjaan, pengeluaran keluarga, dan besar keluarga. Usia responden dikategorikan menjadi dewasa awal (18-40 tahun), dewasa madya (40-60 tahun), dan dewasa lanjut ( $>60$ tahun). Pendidikan responden diukur berdasarkan pendidikan formal terakhir yang telah ditempuh, terdiri atas SD, SMP, SMA, Diploma, S1, dan S2. Pekerjaan responden adalah jenis pekerjaan yang sehari-hari dilakukan oleh responden untuk mendapatkan penghasilan guna memenuhi kebutuhan hidup, terdiri atas PNS/TNI, karyawan swasta, ibu rumah tangga, buruh, wirausahawan/dagang, dan profesi (dokter, bidan, guru).

Pengeluaran keluarga diukur dengan menggunakan skala interval AC Nielsen. Besar keluarga responden dikategorikan menjadi keluarga kecil (1-4 orang), sedang (5-6 orang), dan besar ( $\geq 7$ orang). Pengeluaran keluarga per bulan adalah besarnya uang yang dikeluarkan untuk memenuhi kebutuhan keluarga dalam sebulan. Selanjutnya pengeluaran keluarga dikelompokkan menjadi kurang dari Rp700.000; Rp700.001 sampai dengan Rp1.000.000; Rp1.000.001 sampai dengan Rp1.500.000; Rp1.500.001 sampai dengan Rp2.000.000; Rp2.000.001 sampai dengan Rp3.000.000; Rp3.000.001 sampai dengan Rp5.000.000; dan lebih dari Rp5.000.000.

Preferensi dalam penelitian ini merujuk pada tingkat kesukaan responden terhadap berbagai kombinasi atribut ikan segar dan ikan olahan (habitat/jenis ikan dan kondisi ikan). Pengukuran preferensi menggunakan sistem skoring dengan memberi skor antara 1 sampai dengan 10 kepada masing-masing kombinasi atribut yang diajukan. Skor 1 adalah nilai terendah (tidak suka) dan skor 10 adalah nilai tertinggi (sangat suka).

Sementara itu, pengetahuan dalam penelitian ini merujuk pada semua informasi mengenai produk yang tersimpan dalam memori jangka panjang responden. Pengetahuan diukur dengan 10 pertanyaan. Pertanyaan terdiri atas lima pertanyaan benar dan salah serta lima pertanyaan pilihan ganda. Pertanyaan meliputi pengetahuan mengenai habitat ikan, jenis ikan, manfaat mengonsumsi ikan, dan cara pengolahan ikan. Total skor pengetahuan diperoleh dari hasil penjumlahan skor 10 pertanyaan pengetahuan.

Sikap dalam penelitian ini merujuk pada tindakan responden yang dipengaruhi oleh perasaan, pengetahuan/ kepercayaan dan kebiasaan perilaku. Variabel sikap diukur dengan 8 pertanyaan dan total skor sikap diperoleh melalui penjumlahan delapan pertanyaan sikap. Pengukuran sikap menggunakan Skala Likert yang terdiri atas lima peringkat, yaitu $5=$ sangat setuju, $4=$ setuju, $3=$ netral/ragu-ragu, $2=$ tidak setuju, $1=$ sangat tidak setuju.

Data yang telah dikumpulkan diolah dan dianalisis dengan analisis deskriptif, konjoin, Fishbein, dan logit. Analisis deskriptif dilakukan untuk menganalisis karakteristik ekonomi dan sosial demografi. Analisis Konjoin untuk menganalisis preferensi terhadap atribut ikan. Analisis Fishbein digunakan untuk mengetahui sikap responden terhadap ikan segar dan ikan olahan. Selanjutnya, analisis logit untuk menganalisis variabel-variabel yang berpengaruh terhadap pembelian ikan segar dan ikan olahan pada ibu bekerja dan ibu tidak bekerja. 


\section{HASIL}

\section{Karakteristik Responden}

Berdasarkan hasil penelitian, lebih dari satu per tujuh $(>70,0 \%)$ ibu bekerja dan tidak bekerja temasuk usia dewasa awal. Lebih dari setengah $(>50,0 \%)$ ibu bekerja dan tidak bekerja pendidikan terakhirnya adalah $\mathrm{S} 1$. Selanjutnya, sebanyak 30,0 persen ibu bekerja sebagai karyawan swasta. Pada kelompok ibu bekerja, persentase terbesar $(31,0 \%)$ untuk pengeluaran keluarga adalah lebih dari Rp5.000.000 per bulan sedangkan pada kelompok ibu tidak bekerja sebanyak 32,0 persen memiliki pengeluaran keluarga antara Rp3.000.000 sampai dengan Rp5.000.000 per bulan. Temuan penelitian lainnya adalah sebanyak setengah ibu bekerja dan ibu tidak bekerja memiliki jumlah anggota keluarga antara satu hingga empat orang atau termasuk keluarga kecil (Tabel 1).

Tabel 1 Sebaran karakteristik responden

\begin{tabular}{lrr}
\hline Karakteristik & \multicolumn{2}{c}{ Status pekerjaan ibu } \\
\cline { 2 - 3 } & $\begin{array}{c}\text { Bekerja } \\
(\%)\end{array}$ & $\begin{array}{c}\text { Tidak } \\
\text { Bekerja }(\%)\end{array}$ \\
\hline Usia & & \\
18-40 tahun & 79,0 & 74,0 \\
41-60 tahun & 21,0 & 25,0 \\
>60 tahun & 0,0 & 1,0 \\
Jumlah & 100,0 & 100,0 \\
\hline Tingkat Pendidikan & & \\
Sekolah Dasar & 0,0 & 3,0 \\
Sekolah menengah & 1,0 & 6,0 \\
Pertama & 7,0 & 15,0 \\
Sekolah Menengah Atas & 19,0 & 20,0 \\
Diploma & 58,0 & 55,0 \\
Strata 1 & 15,0 & 1,0 \\
Strata 2 & 100,0 & 100,0 \\
Jumlah & & \\
\hline Jenis Pekerjaan & 0,0 & 100,0 \\
lbu Rumah Tangga & 30,0 & 0,0 \\
Karyawan swasta & 41,0 & 0,0 \\
PNS/TNI & 13,0 & 0,0 \\
Profesi (Dokter/bidan) & 16,0 & 0,0 \\
Wirausaha/dagang & 100,0 & 100,0 \\
Jumlah & & \\
\hline Pengeluaran keluarga/bulan & \\
<700.000 & 0,0 & 0,0 \\
700.001-1.000.000 & 6,0 & 6,0 \\
1.000.001-1.500.000 & 9,0 & 12,0 \\
1.500.001-2.000.000 & 9,0 & 15,0 \\
2.000.001-3.000.000 & 22,0 & 15,0 \\
3.000.001-5.000.000 & 23,0 & 32,0 \\
>5.000.000 & 31,0 & 20,0 \\
Jumlah & 100,0 & 100,0 \\
\hline Jumlah anggota & & \\
keluarga & & \\
1-4 orang & 55,0 & 52,0 \\
5-6 orang & 6,0 & 45,0 \\
>6 orang & 3,0 \\
Jumlah & 100,0 & 100,0 \\
\hline & & \\
\hline
\end{tabular}

Tabel 2 Sebaran responden berdasarkan preferensi terhadap ikan segar dan ikan olahan

\begin{tabular}{lcr}
\hline \multirow{2}{*}{ Atribut } & \multicolumn{2}{c}{ Status Pekerjaan Ibu } \\
\cline { 2 - 3 } & Bekerja & Tidak bekerja \\
\hline Nilai Kepentingan Taraf (NKT) & \\
Habitat/jenis & & \\
Tawar & & \\
Laut & -0.1933 & -0.1900 \\
\hline Kondisi & 0.1933 & 0.1900 \\
Hidup & & \\
Dibersihkan & -0.1017 & 0.0900 \\
Diolah & 0.4233 & 0.4550 \\
\hline Nilai Relatif Penting (NRP) & -0.3217 & -0.5450 \\
Habitat/jenis & & \\
Tawar & \\
Laut & 34.168 & 27.536 \\
\hline Kondisi & & \\
Hidup & & \\
Dibersihkan & & \\
Diolah & 65.832 & 72.464 \\
\hline
\end{tabular}

Hasil analisis uji beda $t$-test menemukan bahwa terdapat perbedaan nyata dan signifikan $(p=0,000)$ antara pendidikan ibu bekerja dengan ibu tidak bekerja, yaitu pendidikan ibu bekerja lebih tinggi dibandingkan dengan ibu tidak bekerja. Sementara itu, tidak ditemukan perbedaan nyata dan signifikan $(p>0,05)$ berkaitan dengan usia, pengeluaran keluarga per bulan, dan jumlah anggota keluarga anta ibu bekerja dan ibu tidak bekerja.

\section{Preferensi terhadap Ikan Segar dan Ikan Olahan}

Kotler (1997) mendefinisikan preferensi konsumen sebagai pilihan suka atau tidak suka yang dilakukan oleh seseorang terhadap produk (barang atau jasa) yang dikonsumsi. Hasil analisis konjoin menunjukkan bahwa ibu bekerja dan ibu tidak bekerja lebih mementingkan atribut kondisi ikan dibandingkan dengan atribut habitat/jenis ikan. Perbedaan hasil analisis preferensi antara ibu bekerja dan ibu tidak bekerja terletak pada besarnya nilai relatif penting (NRP) dan nilai kepentingan taraf (NKT). NRP dan NKT dapat dilihat pada Tabel 2.

\section{Pengetahuan terhadap Ikan Segar dan Ikan Olahan}

Berdasarkan hasil analisis, tingkat pengetahuan ibu bekerja terhadap ikan segar termasuk dalam kategori sedang $(49,0 \%)$ dan baik $(49,0 \%)$. Selanjutnya, tingkat pengetahuan ibu bekerja terhadap ikan olahan termasuk dalam kategori baik (83,0\%). Sementara itu, tingkat pengetahuan ibu yang tidak bekerja terhadap 
ikan segar $(60,0 \%)$ dan ikan olahan $(80,0 \%)$ termasuk dalam kategori baik. Hasil analisis uji beda $t$-test menunjukkan tidak terdapat perbedaan nyata dan signifikan antara pengetahuan tentang ikan segar dan ikan olahan pada ibu bekerja dan ibu tidak bekerja.

\section{Sikap terhadap Ikan Segar dan Ikan Olahan}

Hasil penelitian yang disajikan pada Tabel 3 menunjukkan bahwa ibu bekerja dan tidak bekerja mempunyai sikap yang sama yaitu lebih menyukai ikan segar dibandingkan dengan ikan olahan. Hal ini terlihat dari nilai rata-rata analisis Fishbein sikap terhadap ikan segar (ibu bekerja $=57,2$; ibu tidak bekerja $=50,1$ ) yang lebih tinggi dibandingkan dengan nilai rata-rata sikap terhadap ikan olahan (ibu bekerja $=33,8$; ibu tidak bekerja $=29,6$ ) . Selanjutnya, hasil uji beda $t$-test menemukan tidak ada perbedaan nyata antara sikap terhadap ikan segar pada ibu bekerja dan tidak bekerja. Namun, perbedaan nyata ditunjukkan antara sikap terhadap ikan olahan pada ibu bekerja dan ibu tidak bekerja $(p=0,001)$, yaitu sikap ibu bekerja terhadap ikan olahan lebih tinggi penerimaannya dibandingkan dengan ibu tidak bekerja.

\section{Pembelian Ikan Segar dan Ikan Olahan}

Pembelian ikan segar dan ikan olahan pada ibu bekerja dan ibu tidak bekerja dihitung berdasarkan frekuensi (per bulan) dan kuantitas pembelian ikan (per transaksi). Hasil penelitian menemukan hampir setengah ibu bekerja $(42,0 \%)$ dan ibu tidak bekerja $(42,0 \%)$ membeli ikan segar sebanyak 4-8 kali per bulan. Selanjutnya, persentase tertinggi frekuensi pembelian ikan olahan oleh ibu bekerja $(68,0 \%)$ dan ibu tidak bekerja $(61,0 \%)$ adalah kurang dari empat kali per bulan.

Tabel 3 Hasil analisis Fishbein pada sikap responden terhadap ikan segar dan ikan olahan

\begin{tabular}{lccccc}
\hline \multirow{2}{*}{ Analisis } & \multicolumn{2}{c}{ lbu Bekerja } & \multicolumn{2}{c}{ lbu Tidak Bekerja } \\
\cline { 2 - 6 } & & $\mathrm{A}$ & $\mathrm{B}$ & $\mathrm{A}$ & $\mathrm{B}$ \\
\hline Ikan & 1 & 3,8 & 3,9 & 3,5 & 3,5 \\
segar & 2 & 3,9 & 3,9 & 3,6 & 3,5 \\
& 3 & 3,9 & 3,7 & 3,9 & 3,4 \\
& 4 & 3,7 & 3,4 & 3,2 & 3,2 \\
\hline Nilai & \multicolumn{4}{c}{57,2} & \multicolumn{4}{c}{50,1} \\
\hline Ikan & 1 & 3,0 & 2,7 & 2,7 & 2,6 \\
olahan & 2 & 2,5 & 2,5 & 2,5 & 2,5 \\
& 3 & 2,7 & 3,3 & 2,6 & 2,9 \\
& 4 & 3,3 & 2,7 & 2,9 & 2,5 \\
\hline Nilai & \multicolumn{4}{c}{33,8} \\
\hline
\end{tabular}

Keterangan: A: Keyakinan, B: Evaluasi
Tabel 4 Sebaran responden berdasarkan frekuensi dan kuantitas pembelian ikan segar dan ikan olahan

\begin{tabular}{|c|c|c|c|c|}
\hline \multirow{3}{*}{ Kategori } & \multicolumn{4}{|c|}{ Status Pekerjaan Ibu } \\
\hline & \multicolumn{2}{|c|}{ Bekerja (\%) } & \multicolumn{2}{|c|}{ Tidak Bekerja (\%) } \\
\hline & IS & 10 & IS & 10 \\
\hline \multicolumn{5}{|c|}{ Frekuensi Pembelian per Bulan } \\
\hline$<4$ kali & 35,0 & 68,0 & 28,0 & 61,0 \\
\hline 4-8 kali & 42,0 & 23,0 & 42,0 & 23,0 \\
\hline 9-12 kali & 16,0 & 7,0 & 19,0 & 4,0 \\
\hline 13-16 kali & 2,0 & 2,0 & 10,0 & 10,0 \\
\hline$>17$ kali & 5,0 & 0,0 & 1,0 & 2,0 \\
\hline Jumlah & 100,0 & 100,0 & 100,0 & 100,0 \\
\hline \multicolumn{5}{|c|}{ Kuantitas Pembelian per Transaksi } \\
\hline$<1,0 \mathrm{k}$ & 41,0 & 67,0 & 39,0 & 79,0 \\
\hline $1,1-2,0 \mathrm{~kg}$ & 54,0 & 28,0 & 53,0 & 18,0 \\
\hline $2,1-3,0 \mathrm{~kg}$ & 4,0 & 4,0 & 5,0 & 1,0 \\
\hline$>3,0 \mathrm{~kg}$ & 1,0 & 1,0 & 3,0 & 2,0 \\
\hline Jumlah & 100,0 & 100,0 & 100,0 & 100,0 \\
\hline
\end{tabular}

Keterangan: IS: Ikan segar; IO: Ikan olahan

Berdasarkan kuantitasnya, lebih dari setengah ibu bekerja $(54,0 \%)$ dan ibu tidak bekerja $(53,0 \%)$ membeli ikan segar sebanyak 1,1-2 kilogram. Sementara itu, sebanyak 67,0 persen ibu bekerja dan 79,0 persen ibu tidak bekerja membeli ikan olahan kurang dari 1 kilogram per transaksi (Tabel 4). Hasil analisis uji beda $t$ menemukan bahwa tidak terdapat perbedaan nyata dan signifikan $(p>0,05)$ dalam frekuensi pembelian ikan segar pada ibu bekerja dan ibu tidak bekerja. Namun terdapat perbedaan nyata dan signifikan $(p=0,04)$ dalam frekuensi pembelian ikan olahan pada ibu bekerja dan ibu tidak bekerja. Hasil uji beda $t$ test juga menemukan tidak terdapat perbedaan nyata dan signifikan $(p>0,05)$ antara kuantitas pembelian ikan segar dan ikan olahan pada ibu bekerja dan ibu tidak bekerja.

\section{Faktor yang Memengaruhi Pembelian Ikan Segar dan Ikan Olahan}

Analisis logit dilakukan untuk menganalisis variabel yang berpengaruh terhadap perilaku pembelian ikan segar dan ikan olahan. Variabel independen yang diuji adalah variabel sosial demografi responden, preferensi terhadap ikan segar dan ikan olahan, pengetahuan tentang ikan segar dan ikan olahan, dan sikap terhadap ikan segar dan ikan olahan. Variabel sosial demografi meliputi usia, pendidikan, pengeluaran keluarga, besar keluarga dan status pekerjaan. Variabel dependennya adalah frekuensi dan kuantitas pembelian ikan segar dan ikan olahan. Variabel dengan nilai signifikansi kurang dari 0,05 merupakan variabel yang signifikan memengaruhi variabel dependen pada selang kepercayaan 5,0 persen. 
Tabel 5 Variabel yang berpengaruh pada perilaku pembelian ikan segar dan ikan olahan

\begin{tabular}{|c|c|c|c|c|c|c|c|}
\hline \multirow[b]{2}{*}{ Variabel } & \multirow[b]{2}{*}{ Estimate } & \multirow[b]{2}{*}{$\begin{array}{l}\text { Std. } \\
\text { Error }\end{array}$} & \multirow[b]{2}{*}{ Wald } & \multirow[b]{2}{*}{ Df } & \multicolumn{3}{|c|}{ 95\% Confidence Interval } \\
\hline & & & & & Sig & $\begin{array}{l}\text { Lower } \\
\text { bound }\end{array}$ & $\begin{array}{l}\text { Upper } \\
\text { bound }\end{array}$ \\
\hline \multicolumn{8}{|l|}{ Frekuensi Pembelian Ikan Segar } \\
\hline $\begin{array}{l}\text { - Pengeluaran Rp700.000,00- } \\
\text { Rp1.000.000,00 }\end{array}$ & $-1,552$ & 0,757 & 4,198 & 1 & 0,040 & $-3,037$ & $-0,067$ \\
\hline - Preferensi suka & $-0,710$ & 0,319 & 4,975 & 1 & 0,026 & $-1,335$ & $-0,086$ \\
\hline - Pengetahuan baik & $-0,644$ & $-0,306$ & 4,436 & 1 & 0,035 & $-1,243$ & $-0,045$ \\
\hline $\begin{array}{l}\text { Frekuensi Pembelian Ikan } \\
\text { Olahan }\end{array}$ & & & & & & & \\
\hline - Pendidikan SD & 3,219 & 1,553 & 4,296 & 1 & 0,038 & 0,175 & 6,262 \\
\hline - Pendidikan SMP & 3,326 & 1,069 & 9,691 & 1 & 0,002 & 1,232 & 5,421 \\
\hline - Besar keluarga (1-4 orang) & $-2,793$ & 0,778 & 12,900 & 1 & 0,000 & $-4,317$ & $-1,269$ \\
\hline - Besar keluarga (5-6 orang) & $-2,512$ & 0,756 & 11,036 & 1 & 0,001 & $-3,994$ & $-1,030$ \\
\hline - Sikap & $-1,901$ & 0,653 & 8,460 & 1 & 0,004 & $-3,181$ & $-0,620$ \\
\hline $\begin{array}{l}\text { Kuantitas Pembelian Ikan Segar } \\
\text { - Pengeluaran Rp700.000,00- } \\
\text { Rp1.000.000,00/bulan }\end{array}$ & $-1,467$ & 0,638 & 5,298 & 1 & 0,021 & $-2,717$ & $-0,218$ \\
\hline $\begin{array}{l}\text { - Pengeluaran Rp1.000.000,00- } \\
\text { Rp1.500.000,00/bulan }\end{array}$ & $-1,228$ & 0,474 & 6,719 & 1 & 0,010 & $-2,156$ & $-0,299$ \\
\hline $\begin{array}{l}\text { Kuantitas Pembelian Ikan } \\
\text { Olahan }\end{array}$ & & & & & & & \\
\hline - Besar keluarga (1-4 orang) & $-1,283$ & 0,645 & 3,957 & 1 & 0,047 & $-2,546$ & $-0,019$ \\
\hline
\end{tabular}

Hasil analisis logit memperlihatkan bahwa faktor yang berpengaruh signifikan terhadap frekuensi pembelian ikan segar adalah pengeluaran keluarga antara Rp700.000,00 sampai dengan Rp1.000.000,00 per bulan, preferensi sedang ter-hadap ikan segar, dan pengetahuan sedang mengenai ikan segar (Tabel 5). Sementara itu, variabel yang berpengaruh pada frekuensi pembelian ikan olahan adalah ibu dengan pendidikan SD, pendidikan SMP, keluarga kecil, keluarga sedang, dan sikap terhadap ikan olahan yang kurang baik. Ibu dengan pendidikan setingkat SD dan SMP lebih berpeluang 3,219 dan 3,326 kali lebih sering melakukan pembelian ikan olahan. Selanjutnya ibu dengan jumlah anggota keluarga kecil (1-4 orang) dan keluarga sedang (4-6 orang) berpeluang lebih rendah dalam frekuensi pembelian ikan olahan. Ibu dengan sikap terhadap ikan olahan kurang baik berpeluang lebih rendah dalam frekuensi pembelian ikan olahan.

Berdasarkan hasil penelitian yang disajikan pada Tabel 5, variabel yang berpengaruh terhadap kuantitas ikan segar yang dibeli adalah pengeluaran antara Rp700.000,00 sampai dengan $\mathrm{Rp} 1.000 .000,00$ per bulan dan juga pengeluaran antara Rp1.000.000,00 sampai dengan Rp1.500.000,00 per bulan . Pengeluaran rumah tangga per bulan tersebut berpeluang membeli ikan segar dalam kuantitas lebih rendah. Variabel yang berpengaruh terhadap kuantitas ikan olahan yang dibeli adalah jumlah anggota keluarga. Keluarga kecil (1-4 orang) mempunyai peluang lebih sedikit membeli ikan olahan.

\section{PEMBAHASAN}

Preferensi dapat didefinisikan sebagai pilihan suka atau tidak suka terhadap suatu barang/jasa yang dikonsumsi. Menurut Adiyoga dan Nurmalinda (2012) dan Cerda et al. (2012), karakteristik kualitas suatu produk yang diinginkan konsumen dapat diperoleh melalui pengkajian terhadap perilaku konsumen berdasarkan pendekatan konsep atribut produk. Analisis konjoin secara luas telah digunakan dalam menganalisis preferensi konsumen di sektor pertanian dan pangan, misalnya untuk sagu (Palembang, 2015), buah jeruk (Herista, 2015), dan cabai keriting (Endiyani, 2014).

Atribut pada penelitian ini meliputi habitat/jenis ikan (ikan tawar dan ikan laut) dan kondisi ikan (hidup/mati, sudah dibersihkan, sudah diolah). Menurut Harlin (2008), terjadinya perubahan preferensi konsumen dapat ditunjukkan dengan semakin banyaknya atribut suatu produk yang harus dievaluasi. Hasil analisis konjoin menunjukkan bahwa ibu bekerja dan ibu tidak bekerja lebih mementingkan atribut kondisi ikan dibandingkan dengan atribut habitat/jenis ikan. Hal ini tidak sesuai dengan 
penelitian Lebiedzinska et al. (2006) dan Obiero et al. (2014) yang menyebutkan bahwa atribut yang diutamakan oleh konsumen adalah kualitas produk secara keseluruhan, kemudahan mendapatkan, dan rasa.

Ibu bekerja dan ibu tidak bekerja berpendapat bahwa ikan tawar dan ikan laut mempunyai kandungan gizi yang sama baik sehingga jenis ikan tidak menjadi prioritas utama ketika membeli ikan. Ibu bekerja lebih menyukai ikan dengan kondisi sudah dibersihkan. Ibu mengutamakan untuk membeli ikan yang sudah dibersihkan oleh penjual ikan. Ikan tersebut telah dibersihkan dari sisik, insang, dan bagian perut sehingga ibu tidak perlu repot membersihkan ikan sesampainya di rumah. Ikan yang dibeli dengan kondisi sudah bersih akan menghemat waktu ibu untuk mengolah dan menyajikan sebagai menu bagi keluarganya. Hasil ini sejalan dengan penelitian Matlabi et al. (2013) yang menyebutkan bahwa kemudahan untuk mempersiapkan dan memasak ikan menjadi salah satu faktor yang memengaruhi konsumsi ikan selain faktor aroma dan rasa ikan dan juga ketakutan terhadap tulang ikan.

Alasan lain yang menyebabkan ibu bekerja dan ibu tidak bekerja lebih menyukai ikan segar daripada ikan olahan adalah karena ikan segar lebih enak rasanya. Ikan segar mengandung nutrisi yang lebih baik dibandingkan dengan ikan olahan dan dapat disajikan menjadi beraneka jenis masakan. Aneka jenis masakan ikan segar membuat anggota keluarga lebih berminat untuk mengonsumsi ikan. Hal inilah yang membuat preferensi kedua kelompok ibu lebih baik terhadap ikan segar dibandingkan dengan ikan yang sudah diolah.

Ibu bekerja dan ibu tidak bekerja lebih menyukai ikan laut dibandingkan dengan ikan tawar. Meskipun harga ikan laut relatif lebih mahal dibandingkan dengan ikan tawar. Penyebabnya terletak pada perbedaan rasa. Rasa ikan tawar hasil tangkapan maupun budidaya biasanya seperti berbau lumpur. Hal ini terjadi karena pada habitat ikan tawar banyak terdapat lumut yang merupakan makanan ikan sehingga daging ikan menjadi berbau lumpur.

Kesamaan preferensi antara ibu bekerja dan tidak bekerja ini disebabkan oleh adanya kesamaan pengetahuan dan budaya. Suku ibu bekerja dan ibu tidak bekerja yang menjadi responden sebagian besar adalah Suku Jawa dan Sunda sehingga mempunyai nilai-nilai budaya yang hampir sama dan membentuk urutan preferensi yang sama dan hanya berbeda nilai relatif penting dan nilai kepentingan taraf. Menurut Sokib, Palupi, \& Suharjo (2012), preferensi konsumen terhadap ikan dalam bentuk segar dipengaruhi oleh beberapa faktor diantaranya kandungan gizi dan budaya (kebiasaan sejak kecil). Hasil analisis konjoin dalam penelitian ini sesuai dengan pola preferensi dalam penelitian Sokib, Palupi, dan Suharjo (2012) yang memperlihatkan pola homogen, yakni suka pada ikan dalam bentuk segar sebanyak 78,0 persen, baik ikan air tawar maupun ikan air laut dibandingkan ikan dalam bentuk olahan sebesar 22,0 persen. Harlin (2008) juga menemukan hasil yang sama bahwa preferensi dalam mengonsumsi ikan olahan di Kota Bekasi jauh lebih rendah dibandingkan dengan preferensi terhadap ikan segar.

Ibu bekerja dan ibu tidak bekerja memiliki pengetahuan yang sama terhadap ikan segar dan ikan olahan. Kedua lbu sebagian besar memiliki nilai pengetahuan mengenai ikan segar dengan kategori sedang dan baik. Pengetahuan yang dimiliki oleh ibu bekerja menjadikan ibu bekerja tetap memilih ikan segar ke dalam menu keluarga meskipun mempunyai waktu yang lebih sedikit dalam menyajikan menu makanan ikan bagi keluarga. Hal ini didasari oleh pengetahuan mengenai kandungan gizi dan manfaat mengonsumsi ikan bagi kesehatan tubuh. Indriana dan Widajanti (2005) menyatakan bahwa semakin tinggi pengetahuan gizi seseorang maka akan semakin memperhitungkan jenis dan jumlah makanan yang dipilih untuk dikonsumsi. Hal ini juga sesuai dengan Sediaoetama (1993) bahwa orang yang pengetahuan gizinya rendah akan berperilaku memilih makanan yang menarik panca indera dan tidak mengadakan pilihan berdasarkan nilai gizi makanan. Sebaliknya mereka yang bagus pengetahuan gizinya lebih banyak mempergunakan pertimbangan rasio dan pengetahuan tentang nilai gizi makanan tersebut. Hal ini juga sesuai dengan hasil penelitian Pieniak et al. (2008) yang menyatakan bahwa keinginan menjadi sehat merupakan pemicu secara tidak langsung konsumsi ikan. Khuril'in (2015) menyatakan pengetahuan gizi ibu berpengaruh terhadap konsumsi ikan dikarenakan ibu adalah penyedia makanan dalam rumah tangga.

Pengetahuan seseorang yang biasanya diperoleh dari pengalaman yang berasal dari berbagai macam sumber, misalnya media masa, media elektronik, buku petunjuk dan 
kerabat dekat. Pengetahuan yang dimiliki dapat membentuk keyakinan tertentu sehingga seseorang berperilaku sesuai dengan kenyataan tersebut. Pengetahuan ibu bekerja dan tidak bekerja didukung oleh pendidikan yang diterimanya. Pendidikan ibu bekerja dan ibu tidak bekerja yang menjadi responden sebagian besar adalah sarjana dan pascasarjana. Waysima et al. (2011b) mengemukakan bahwa tingkat pendidikan ibu membantu keyakinan ibu terhadap pengetahuan yang lebih luas daripada pengetahuan tentang gizi ikan laut. Tingkat pendidikan orang tua akan meningkatkan diantaranya kepemilikan pengetahuan tentang kesehatan dan pangan sehat bagi keluarganya. Ibu bekerja dan ibu tidak bekerja juga mengonsumsi ikan olahan, akan tetapi porsi ikan olahan tidak sebanyak ikan segar dalam menu keluarga. Hal ini dilandasi oleh pengetahuan ibu bekerja dan ibu tidak bekerja untuk menyediakan makanan yang penuh gizi bagi keluarga.

Analisis Fishbein terhadap keyakinan responden memperlihatkan bahwa atribut khasiat dan manfaat adalah yang paling bagus kinerjanya menurut ibu bekerja. Ibu bekerja mempunyai keyakinan bahwa khasiat dan manfaat ikan segar adalah paling utama dibanding kandungan gizi dan keunggulan ikan segar dibandingkan lauk lainnya. Ibu bekerja mengharapkan khasiat bagi kesehatan setelah mengonsumsi ikan segar dan hasilnya adalah sesuai yang diharapkan oleh ibu bekerja. Hal ini sesuai dengan penelitian Irianto (2015) yang menyebutkan bahwa kesadaran terhadap kesehatan merupakan penentu pada sikap positif individu dalam membeli makanan organik. Keyakinan ibu bekerja terhadap manfaat mengonsumsi ikan segar dan keunggulan ikan segar dibandingkan lauk lainnya lebih tinggi dibandingkan nilai evaluasinya. Hal ini memperlihatkan bahwa ibu bekerja mempunyai harapan yang tinggi ketika akan mengonsumsi ikan segar. Namun setelah mengonsumsi ikan segar manfaat dan keunggulan ikan segar tidak dirasakan berbeda dengan mengonsumsi sumber protein lainnya. Hal ini menyebabkan nilai evaluasi atribut manfaat dan keunggulan ikan segar lebih rendah dibandingkan dengan nilai keyakinannya.

Secara keseluruhan, ibu bekerja lebih menyukai ikan segar dibandingkan dengan ikan olahan. Hal ini terlihat dari penilaian keyakinan dan evaluasi yang lebih tinggi pada ikan segar dibandingkan dengan ikan olahan pada seluruh atribut yang dinilai. Tingginya nilai sikap ibu bekerja terhadap ikan segar disebabkan karena tingginya nilai keyakinan dan evaluasi mengenai kandungan, khasiat, manfaat, dan keunggulan ikan segar. Nilai sikap ibu bekerja terhadap ikan olahan rendah karena keyakinan dan evaluasinya tidak setinggi keyakinan dan evaluasi pada ikan segar. Beberapa alasan ibu bekerja mengonsumsi ikan olahan adalah karena praktis/mudah disajikan dan lebih banyak tersedia di lingkungan tempat tinggal.

Ibu tidak bekerja yakin bahwa atribut manfaat adalah yang paling bagus kinerjanya. Berbeda dengan ibu bekerja, bagi ibu tidak bekerja setelah manfaat mengonsumsi ikan urutan yang disukai selanjutnya adalah khasiat mengonsumsi ikan segar bagi kesehatan, setelah itu adalah kandungan gizi dan disusul dengan keunggulan ikan segar dibandingkan lauk lainnya. Nilai evaluasi ibu tidak bekerja terhadap ikan segar memperlihatkan hal yang berbeda dengan nilai keyakinannya, yaitu atribut manfaat mengonsumsi ikan segar ternyata yang paling penting untuk dipertimbangkan dalam membeli ikan segar. Atribut yang disukai selanjutnya adalah kandungan gizi, khasiat bagi kesehatan, dan keunggulan ikan segar dibandingkan lauk lainnya.

Ibu tidak bekerja mempunyai keyakinan bahwa konsumsi ikan segar akan sangat bermanfaat. Nilai evaluasi yang diberikan oleh ibu tidak bekerja sesuai dengan harapan. Ibu tidak bekerja merasa bahwa harapan memperoleh manfaat setelah mengonsumsi ikan segar telah terpenuhi, yaitu tubuh menjadi lebih sehat dan tidak mudah sakit. Hal ini sesuai dengan hasil penelitian Waysima et al. (2011b) yang menyebutkan bahwa respondennya terutama yang tinggal di wilayah pesisir menunjukkan bahwa generasi mereka jarang mengalami dampak buruk setelah makan ikan laut. Disamping itu, ikan laut sangat bermanfaat bagi kecerdasan dan kesehatan manusia khususnya anak. Secara keseluruhan ibu tidak bekerja lebih menyukai ikan segar dibandingkan dengan ikan olahan. Namun demikian, ibu yang tidak bekerja masih mengonsumsi ikan olahan karena ikan olahan mempunyai banyak kelebihan, diantaranya adalah ikan olahan mudah ditemukan di lingkungan tempat tinggal, harga terjangkau dan mempunyai daya simpan lebih lama dibandingkan ikan segar.

Berdasarkan analisis logit, pengeluaran, preferensi, dan pengetahuan tentang ikan segar dan ikan olahan memengaruhi frekuensi 
pembelian ikan segar dan ikan olahan. Keluarga dengan pengeluaran Rp700.000,00 sampai dengan Rp1.000.000,00 per bulan mempunyai probabilitas yang lebih rendah untuk membeli ikan segar. Beberapa jenis ikan tawar dan laut harganya lebih ekonomis dibandingkan dengan daging ayam maupun daging sapi. Namun demikian masih banyak keluarga yang tidak mampu membeli ikan dalam jumlah yang cukup bagi keluarganya. Pengeluaran keluarga memper-lihatkan tingkat ekonomi dari suatu keluarga. Pengeluaran keluarga yang semakin besar mengindikasikan semakin tinggi tingkat ekonomi keluarga tersebut. Keluarga dengan pengeluaran kurang dari Rp1.500.000,00 per bulan termasuk dalam keluarga ekonomi menengah. Keluarga ini tidak membeli ikan dengan frekuensi yang tinggi karena masih terdapat bahan pangan yang dianggap dapat menggantikan ikan sebagai sumber protein. Bahan pangan pengganti tersebut berasal dari protein nabati/tumbuhan. Hasil ini sesuai dengan penelitian Indriana dan Widajanti (2005) yang menganalisis hubungan antara ketersediaan ikan dalam keluarga dengan pendapatan per kapita per bulan. Apabila pendapatan per kapita per bulan tinggi maka ketersediaan ikan di keluarga juga akan tinggi.

Menurut Baliwati dan Saputra (2014), konsumsi pangan ikan dan pangan hewani lainnya dari penduduk Jawa Barat pada tahun 2012 tergolong rendah. Ibu dengan preferensi sedang terhadap ikan segar mempunyai probabilitas lebih rendah untuk membeli ikan segar. Preferensi sangat memengaruhi perilaku seseorang. Ibu yang preferensinya kurang menyukai ikan segar maka akan rendah frekuensi pembelian ikan segarnya. Pengetahuan kategori sedang terhadap ikan segar mempunyai pengaruh signifikan terhadap frekuensi pembelian ikan segar yang mana ibu dengan pengetahuan sedang mempunyai probabilitas lebih rendah untuk membeli ikan segar. Menurut Indriana dan Widajanti (2005) pengetahuan bahan makanan perlu sebagai dasar untuk menyusun hidangan. Hasil penelitian Indriana dan Widajanti (2005) menyebutkan bahwa terdapat hubungan yang sangat signifikan antara pengetahuan gizi ibu tentang ikan dengan ketersediaan ikan di tingkat keluarga. Hal inilah yang mendasari ibu dengan pengetahuan yang sedang mengenai kandungan gizi ikan, manfaat mengonsumsi ikan dan cara mengolah ikan segar membeli ikan segar dengan frekuensi lebih rendah. Pendidikan ibu memengaruhi pengetahuannya mengenai kandungan gizi, manfaat mengonsumsi dan cara mengolah ikan. Pengetahuan ikan segar pada ibu menyebabkan ibu merasa penting untuk membeli ikan segar bagi keluarganya, namun ibu dengan pengetahuan yang sedang kurang mementingkan untuk membeli ikan segar, sehingga kurang sering membeli ikan segar.

Variabel yang berpengaruh pada frekuensi pembelian ikan olahan berdasakan hasil analisis logit adalah pendidikan, jumlah anggota keluarga dan sikap ibu terhadap ikan olahan. Ibu dengan pendidikan sekolah dasar dan sekolah menengah pertama mempunyai probabilitas lebih tinggi untuk membeli ikan olahan. Ibu dengan latar pendidikan sekolah dasar dan sekolah menengah pertama mempunyai pengetahuan yang kurang mengenai manfaat ikan segar untuk dikonsumsi, sehingga lebih memilih ikan olahan. Hal ini terjadi karena lebih mudah mendapatkan ikan olahan di lingkungan tempat tinggal, lebih mudah dimasak dan tahan lama. Hal ini sesuai dengan penelitian Can, Gunlu, dan Can (2015) yang menyebutkan bahwa perbedaan yang signifikan pada konsumsi ikan ditemukan pada kelompok usia, jenis kelamin, dan pendidikan responden.

Pengetahuan mengenai ikan olahan yang baik membuat ibu bekerja dan ibu tidak bekerja mengetahui kelebihan dan kekurangan mengonsumsi ikan olahan. Ikan olahan merupakan ikan segar yang dibuat dalam berbagai bentuk olahan. Ikan olahan lebih lama daya simpannya karena menggunakan metode dalam pengawetannya. Proses pembuatan ikan olahan telah mengurangi kandungan gizi pada ikan, sedangkan bahan pengawet yang ditambahkan pada ikan olahan untuk memperpanjang daya simpan merupakan hal yang dihindari dalam konsumsi makanan. Jumlah anggota keluarga kecil dan sedang mempunyai probabilitas lebih rendah untuk membeli ikan olahan. Keluarga dengan jumlah kurang dari 6 orang termasuk dalam keluarga sedang. Pembelian ikan olahan mempunyai probabilitas lebih rendah karena kebutuhan konsumsinya lebih sedikit dibandingkan dengan keluarga dengan jumlah anggota yang besar. Hal ini sesuai dengan Onurlubas (2013) yang menyebutkan bahwa jumlah anggota dalam suatu keluarga memengaruhi secara statistik konsumsi ikan. Sikap ibu terhadap ikan olahan mempunyai pengaruh yang signifikan terhadap frekuensi pembelian ikan olahan dimana ibu dengan sikap kategori kurang baik terhadap ikan olahan mempunyai probabilitas lebih rendah untuk membeli ikan olahan. Ibu bekerja dan ibu tidak bekerja 
mempunyai keyakinan yang kurang terhadap manfaat mengonsumsi ikan olahan sehingga kurang tertarik untuk membeli ikan olahan. lbu bekerja dan ibu tidak bekerja yang mempunyai sikap kurang menyukai ikan olahan berarti keyakinan/harapan dan evaluasi terhadap ikan olahannya rendah, sehingga tidak atau kurang memilih ikan olahan sebagai menu keluarga.

Pembelian ikan segar dan ikan olahan juga dilihat dari kuantitas pembelian. Hasil analisis menunjukkan bahwa variabel yang berpengaruh terhadap kuantitas pembelian ikan segar berdasarkan hasil analisis logistik adalah variabel pengeluaran yaitu keluarga dengan pengeluaran antara Rp700.000,00 sampai dengan Rp1.000.000,00 per bulan dan Rp1.000.001,00 sampai dengan Rp1.500.000,00 per bulan mempunyai probabilitas lebih sedikit untuk membeli ikan segar. Hal ini terjadi karena rendahnya daya beli dari keluarga untuk membeli protein hewani berupa ikan segar. Menurut hasil penelitian Yilmaz et al. (2014), konsumsi ikan secara langsung dipengaruhi oleh status pendapatan keluarga. Variabel yang berpengaruh terhadap kuantitas pembelian ikan olahan berdasarkan hasil analisis logistik adalah jumlah anggota keluarga kecil yang mana keluarga kecil mempunyai probabilitas lebih sedikit membeli ikan olahan. Ibu yang mempunyai jumlah anggota keluarga kategori kecil membeli ikan olahan dengan kuantitas sedikit. Hal ini terjadi karena keluarga kecil hanya membutuhkan sedikit ikan olahan untuk memenuhi kebutuhan konsumsi keluarga. Keluarga kecil membeli ikan olahan dan ikan segar dalam jumlah sedikit untuk memenuhi kebutuhan keluarga.

\section{SIMPULAN DAN SARAN}

Perilaku pembelian ikan pada ibu bekerja dan ibu tidak bekerja meliputi frekuensi dan kuantitas pembelian ikan segar dan ikan olahan. Hasil penelitian menunjukkan bahwa tidak ada perbedaan perilaku ibu bekerja dan ibu tidak bekerja terhadap frekuensi pembelian ikan segar dan juga pada kuantitas pembelian ikan segar dan ikan olahan. Perbedaan perilaku terletak pada frekuensi pembelian ikan olahan. Ibu bekerja lebih tinggi frekuensi pembelian olahan dibandingkan dengan ibu tidak bekerja.

Ibu bekerja dan ibu tidak bekerja memiliki preferensi yang sama terhadap atribut ikan, yaitu ibu lebih mementingkan kondisi dibandingkan dengan jenis ikan. Kondisi ikan yang paling disukai oleh ibu bekerja dan ibu tidak bekerja adalah ikan yang sudah dibersihkan/dibuang sisik, insang dan isi perutnya. Jenis ikan yang disukai oleh ibu bekerja dan ibu tidak bekerja adalah ikan laut.

Pengetahuan ibu bekerja dan ibu tidak bekerja mengenai ikan segar dan ikan olahan juga tidak berbeda. Sebagian besar ibu bekerja dan ibu tidak bekerja mempunyai pengetahuan yang sedang dan baik mengenai kandungan gizi, manfaat mengonsumsi, dan cara mengolah ikan. Sikap ibu bekerja dan ibu tidak bekerja berbeda nyata terhadap ikan segar dan ikan olahan. Perbedaan tersebut disebabkan oleh keyakinan dan evaluasi terhadap atribut ikan segar dan ikan olahan.

Faktor yang memengaruhi frekuensi pembelian ikan segar adalah pengeluaran rumah tangga per bulan, preferensi ibu terhadap ikan segar, dan pengetahuan ibu terhadap ikan segar. Faktor yang memengaruhi frekuensi pembelian ikan olahan adalah pendidikan yang diterima oleh ibu bekerja dan ibu tidak bekerja, jumlah anggota keluarga dan sikap ibu bekerja dan tidak bekerja terhadap ikan olahan. Faktor yang memengaruhi kuantitas pembelian ikan segar adalah pengeluaran rumah tangga per bulan, sedangkan faktor yang memengaruhi pembelian ikan olahan adalah jumlah anggota keluarga.

Hasil penelitian menunjukkan bahwa preferensi ibu bekerja dan ibu tidak bekerja lebih mengutamakan kondisi ikan dibandingkan dengan jenis ikan. Hal ini menunjukkan bahwa ibu lebih menyukai ikan yang siap diolah tanpa harus membersihkannya terlebih dahulu. Oleh karena itu, perlu adanya upaya untuk meningkatkan pengetahuan ibu mengenai cara memilih ikan yang baik, menangani/membersihkan ikan, dan mengolah ikan menjadi menu yang bervariasi. Pengetahuan ibu mengenai manfaat mengonsumsi ikan bagi kesehatan akan menumbuhkan sikap yang baik terhadap konsumsi ikan, sehingga peningkatan pengetahuan diharapkan dapat mendorong ibu untuk meningkatkan konsumsi ikan keluarga-nya.

\section{DAFTAR PUSTAKA}

Adiyoga, W., \& Nurmalinda. (2012). Analisis konjoin preferensi konsumen terhadap atribut produk kentang, bawang merah dan cabai merah. J Wort, 22(3), 292302. 
Baliwati, Y. F., \& Saputra, I. M. (2014). Analisis kemandirian ikan dan pangan hewani lainnya pada 26 kabupaten/kota di Jawa Barat tahun 2012. Jurnal Masyarakat Pengolahan Hasil Perikanan Indonesia, 17(3), 186-196.

Can, M. F., Gunlu, A., \& Can, H. Y. (2015). Fish consumption preferences and factors influencing it. Food Science and Technology, 35(2), 339-346.

Cerda, A., A., Garcia, L. Y., Farias, S. O., \& Ubilla, A. M. (2012). Consumer preferences and willingness to pay for organic apples. Cin. Inv. Agr, 39(1), 4759.

[Ditjen PDSPKP] Direktorat Jenderal Peningkatan Daya Saing. (2015). Milestone Gemarikan (Satu Dawarsa Gerakan Memasyarakatkan Makan Ikan). Jakarta, ID: Ditjen PDSPKP.

Endiyani. (2014). Preferensi konsumen dan analisis rantai nilai produk olahan cabai merah kering (studi kasus wilayah Bogor) (Tesis). Institut Pertanian Bogor, Bogor, Indonesia.

Harlin. (2008). Analisis preferensi konsumen terhadap produk perikanan (studi kasus di Kota Bekasi) (Tesis). Universitas Terbuka, Jakarta, Indonesia.

Herista, M. I. S. (2015). Sikap preferensi konsumen buah jeruk lokal dan buah jeruk impor (kasus Kota Bandar Lampung, Provinsi Lampung) (Tesis). Institut Pertian Bogor, Bogor, Indonesia.

Indriana, S., \& Widajanti, L. (2005). Hubungan pendapatan, pengetahuan gizi ibu dengan ketersediaan ikan tingkat rumah tangga daerah perkotaan. Jurnal Gizi Indonesia, 1(1), 8-14.

Irianto, H. (2015). Consumer's attitude and intention towards organic food purchase: an extension of theory of planned behavior in gender perspective. International Journal of Management, Economics and Social Sciences, 4(1), 17-31.

[KKP] Kementerian Kelautan dan Perikanan. (2014). Laporan kinerja kementerian kelautan dan perikanan tahun 2014. [Internet]. [Diunduh 2016 Februari 1]. Tersedia http://www.kkp.go.id/lakip-2014.html.

Khuril'in, M. L. (2015). Faktor-faktor yang berhubungan dengan konsumsi ikan, sayur dan buah pada anak usia prasekolah di TK LPII, Desa Sawotrap, Kecamatan Gedangan, Kabupaten Sidoarjo. E-Journal Boga, 4(2), 41-46.

Kotler, P. (1997). Marketing management; Analysis, planning, implementation, and control 9th Edition. New Jersey, US: Prentice Hall.

Lebiedzinska, A., Kostrzewa, A., Ryskiewicz, J., Zbikowski, R., \& Szefer, P. (2006). Preferences, consumption and Choice factors of fish and seafood among university students. Pol. J. Food Nutr.Sci, 15(56), 91-96.

Palembang, S. P. (2015). Analisis sikap dan preferensi konsumen dalam mengonsumsi tepung sagu di Kota Ambon (Tesis). Institut Pertanian Bogor, Bogor, Indonesia.

Matlabi, M., Rad, G.S., Mostavafi, F., Mohebi, S., Sani, F. A., Azadbakht, L., \& Tabaraie, Y. (2013). A study on the fish consumption according to health education models constructs in 2012. Bulletin of Environment, Pharmacology and Life Science, 3(1), 57-67.

Obiero KO, Opiyo MA, Munguti JM, Orina PS, Kyule D, Yongo E, Githukia CM, \& Karisa HC. (2014). Consumer preference and marketing of Farmed Nile Tilapia (Oreochromis niloticus) and African Catfish (Clarias gariepinus) in Kenya: case study of Kirinyaga and Vihiga Counties. International Journal of Fisheries and Aquatic Studies, 1(5), 6776.

Onurlubas, E. (2013). The factors affecting fish consumption of the consumers in Kesan township in Edirne. Bulgarian Journal of Agricultural Science, 19(6), 1346-1350.

Pieniak, Z., Verbeke, W., Scholderer, J., Brunso, K., \& Olsen, S. O. (2008). Impact of consumers' health beliefs, health involvement and risk perception on fish consumption a study in five European countries. British Food Journal, 110(9), 898-915.

Salaa, J. (2015). Peran ganda ibu rumah tangga dalam meningkatkan ekonomi keluarga di Desa Tarohan Kecamatan Beo Kabupaten Kepualauan Talaud. Jurnal Holisik, 8(15), 1-16.

Sediaoetama. (1993). Ilmu untuk mahasiswa dan profesi Indonesia. Jakarta, ID: Dian Rakyat. 
Soccol, M. C. H., \& Oetterer, M. (2003). Seafood as functional food. Brazilian Archieves of Biology and technology An International Journal, 46(3), 443-454.

Sokib, N., Palupi, N.S., \& Suharjo, B. (2012). Strategi peningkatan konsumsi ikan di Kota Depok Jawa Barat. Manajemen IKM, 7(2), 166-171.

Sumarwan, U. (2014). Perilaku Konsumen, Teori dan Penerapannya dalam Pemasaran. Jakarta, ID: Ghalia Indonesia.

Susanto E., \& Fahmi A. S. (2012). Senyawa fungsional dari ikan: aplikasinya dalam pangan. Jurnal Aplikasi Teknologi Pangan, 1(4), 95-102.

Waysima, Sumarwan, U., Khomsan, A., \& Zakaria, F. R. (2011a). Persepsi dan sikap afektif ibu mempengaruhi perilaku ibu menyediakan ikan laut dalam menu keluarga. Jurnal IImu Keluarga dan Konsumen, 4(1), 74-81.

Waysima, Sumarwan, U., Khomsan, A., \& Zakaria, F. R. (2011b). Sikap afektif ibu terhadap ikan laut nyata meningkatkan apresiasi anak mengonsumsi ikan laut. Journal of Nutrition and Food, 5(3), 197204.

Yilmaz S., Sen B.E., Kara O., \& Uresin A. 2014. Determining consumers preferences for fish consumption: a study in Antalya Province of Turkey. Journal of Academic Documents for Fisheries and Aquaculture, 2, 49-54. 